\title{
The Role of SAARC on Regional Economic Development
}

\author{
Farhana Kosar \\ Research Scholar \\ Department of International Relations \\ Federal Urdu University of Arts, Sciences \& Technology \\ Karachi-Pakistan \\ farhanakauser0209@gmail.com \\ \& \\ Prof. Dr. Syed Wasimuddin \\ Ex-Chairman \\ Department of International Relations \\ Federal Urdu University of Arts, Sciences \& Technology \\ Karachi-Pakistan \\ dr.wasimuddin2013@gmail.com
}

\begin{abstract}
In the current situation of globally optimised trade, territorial equilibrium has become inevitable. Coordination of monetary policy requires a combined effort of public and private funds. The necessary elements of this combined cycle are, on the public side, the ministries of finance and trade and the Planning and Development Commission and, on the private side, the stock exchange and accounting specialists. In the area of financial inclusion, the development of creation variables (especially labour and business) from one partner country to another is allowed without administrative control from the government. The South Asian Association for Regional Cooperation (SAARC) is additionally trying to reconcile South Asia in the monetary sphere, but at a slow pace. In this paper, we attempt to examine the impact
\end{abstract}


of exchange rate movements on the macroeconomic construction of the consolidation approach. The implication is that such an arrangement is impossible, although this is not the case. Furthermore, such an arrangement should promote closer financial ties between member states and increase their trading power with different countries and currency coalitions.

Keywords: Pakistan, SAARC, India, South Asia, Economic Cooperation

\section{Introduction}

This paper is an attempt to address the issue of energy and development towards major financial incorporation in South Asia in the pre-crisis period. This paper includes an overview of eight countries, namely Afghanistan, Bangladesh, Bhutan, India, Maldives, Nepal, Pakistan and Sri Lanka, which are units of the South Asian Association for Regional Cooperation (SAARC). In this article, we will try to focus in particular on the four main SAARC countries: Pakistan, India, Bangladesh and Sri Lanka. India is by far the largest economy in SAARC, while Pakistan and Bangladesh come second and third. Sri Lanka is another significant economy. These four economies are critical to any sub-local mix and, if viable, India and Pakistan will be the dominant components of any proper understanding of regional mix. Below are the GNP and per capita incomes of the seven South Asian countries, according to World Bank information available in 2019 (The World Bank, 2019).: 


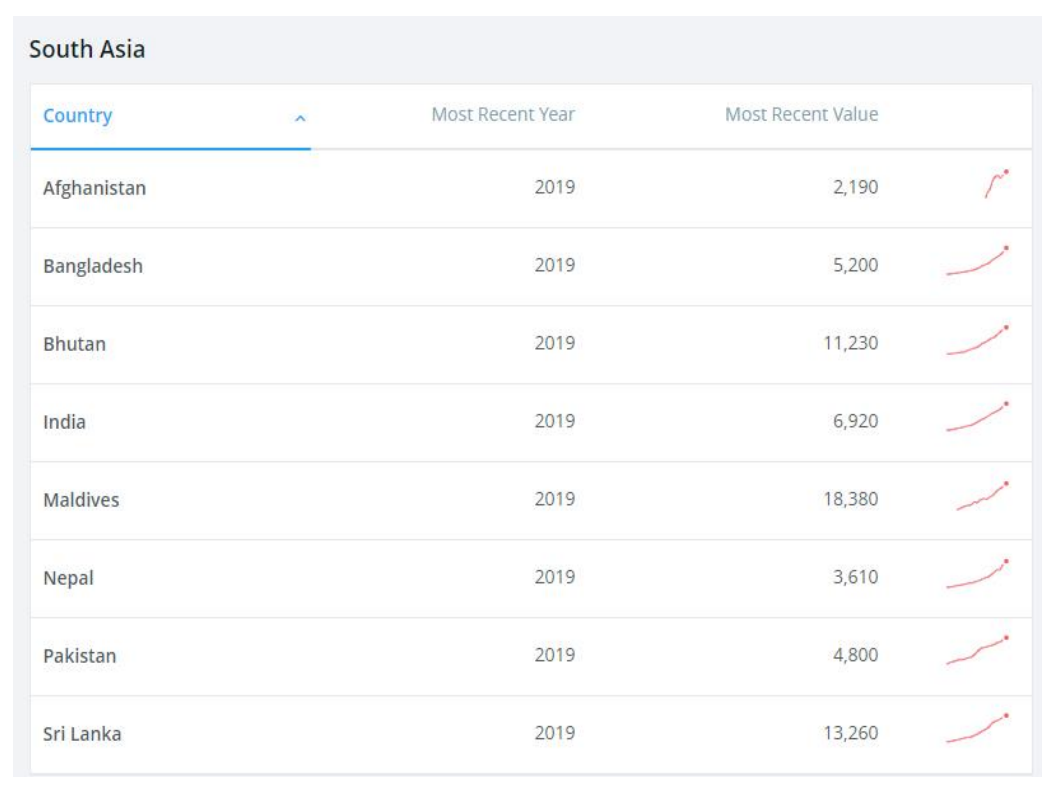

\section{Review of Literature}

Jacob Viner (1950) was the first to study the influence of territorial groupings on state support and introduced the concept of exchange and diversion. In any case, he advanced the proscribed suspicions of null interest and universal service provision. Thus, Mead (1955) relaxed null comprehensiveness to the interest rate. Lipsey (1957) also relaxed the assumption of zero elasticity of equity. The main result of these studies was that if barter creation and barter expansion exceeded barter diversion, the local mix would stimulate government support and vice versa. The study by Wiener, Mead and Lipsey was static and it can be argued that strong preferences may have been more justified. In any case, estimates of dynamic complements also depended on the discussion. Numerous global financial experts came up with different meanings of the combination. As Balassa (1961) notes, reconciliation can be achieved by removing impediments (currency incorporation), promoting factor development (factor coordination), harmonising public money mechanisms (a combination of strategies) and completely unifying these strategies (Balassa 1976). Kitamura (1966) in any case rejects these definitions because, 
although they meet the standards of traditional monetary arrangements, they are not relevant to modern market economies, which are represented by an impressive degree of state intermediation, and even less applicable to creative and communist economies. Pinder (1968) proposed to characterise the monetary mix as the elimination of discrepancies between the financiers of nations, and the organisation and use of co-financed and regular methods to an adequate degree to ensure that the important objectives of financial and governmental assistance are achieved. His definition was rebuked by Vajda (1971) for its oversimplification. Vajda presented a qualification between market involvement and coordination of creation and improvement. The former is characterised as 'ensuring a smooth supply of goods to each other within the structure of the social order of the participating countries'. The latter, in turn, is characterised as "raising to a global level and programming the creation of those parts of the industry that cannot be shaped to ideal sizes within the borders of countries." Vamvakidis (1998), in one of his first attempts, sought to answer the question of whether provincial economic activity affects development. His precise proof showed that it is to the advantage of more modest economies to make such agreements with larger economies to become faster (Anand, 1991).

\section{The Regionalism of South Asia Defined}

Scholars of world relations offer several explanations for regionalism to answer the accompanying question: for what reason do states participate in and agree to agreed sets of rules, thereby placing certain limits on the self-reliance and even fickleness of their mechanisms? According to Arndt, (1968), explanations are briefly presented in two general classifications: (I) power-centred and (ii) institutionalist.

\section{The Power-centred View}

The power-centred view of regionalism assumes that the global structure is essentially anarchic, forcing individual nation-states to assert their control and extend their ownership to ensure their security. Therefore, the politico-military power of states and its diffusion among them has a major impact on relations between states. Cohesion among nation-states in such circumstances must be 
achieved by constantly changing their overall influence on each other. Following this line of thought, the rulers consider regionalism as the response of the states within the district to the control of projection by innovative (authoritative) state(s) outside the district. If such activity is perceived as a threat to their security, states may form an RCA (Regional cooperation arrangements) to pool their resources and comprehensively counter the external enemy. If an authoritative state proves to be out of the territory, states may also consider forming an RCA to bring the subjugated state into a coordinated structure to direct its force operations. Moreover, they may form RCAs when this direction reflects a convergence of their societal interests, e.g. when states join together to use their combined power in a global debate to obtain preferential terms rather than terms that only they could obtain. In sum, an authoritative state can itself encourage the development of RCAs to reduce the coordination costs it normally charges its more modest partners. A look at power actors also confirms that the presence of an unlikely or dominant state is particularly attractive because it can act as a central or significant actor and deal with cumulative activities. Power opponents also find that the inconsistent transfer of KSA gains between states (real or filibustered) is likely to reduce cooperation unless compensatory measures are taken against troubled states. The veracity or impression of inconsistent gains for weaker units may be due to more significant units attributing more gains to themselves as a result of their greater market power and exchange influence. Be that as it may, the comparative result can likewise be derived from the cycle of exchange and financial progress, as the excessive burden of the cost of change occasionally falls on more modest and unsustainable countries. This demonstrates the fundamental significance of payment instruments in sustaining the cycle of provincial inclusion, particularly when each country is at a significantly different degree of viability and improvement (Palmer, 1991).

\section{Institutionalist View}

Institutionalism starts from the fact that the relationship between states is so unpredictable and overwhelming that the ability of a single state to solve its external problems on its own is beyond its capacity. There is therefore a need for local and 


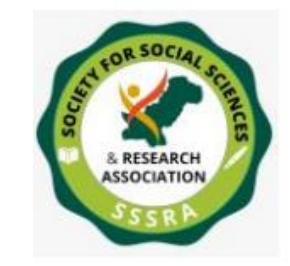

global institutions capable of adequately addressing the global monetary and noneconomic problems that countries face to cope with the aggregate activity. Moreover, such funds can also provide specialised skills to address issues in selected problem areas. These reflections encourage countries to collaborate and create funds that meet clearly defined user requirements. Also, when partner countries begin to benefit from the fund's knowledge and experience in one problem area, they become willing to create comparable organisations to address problems in other areas. Beneficiary parties, political and social assemblies and individuals with a personal interest in this (e.g. global companies, global institutions, unknown powers) also contribute to the expression of interest in new foundations. Such oversaturation leads to the emergence of numerous organisations overseeing issues in different problem areas. The proliferation of practical organisations in different problem regions promotes cross-sectoral ties and better financial coordination between countries and lays the groundwork for their inevitable political unification. Hypothetical explanations for why countries participate, as shown above, do not institutionalism starts from the fact that the relationship between states is so unpredictable and overwhelming that the ability of a single state to solve its external problems on its own is beyond its capacity. There is therefore a need for local and global institutions capable of adequately addressing the global monetary and noneconomic problems that countries face to cope with the aggregate activity.

Moreover, such funds can also provide specialised skills to address issues in selected problem areas. These reflections encourage countries to collaborate and create funds that meet clearly defined user requirements. In addition, when partner countries begin to benefit from the fund's knowledge and experience in one problem area, they become willing to create comparable organisations to address problems in other areas. Beneficiary parties, political and social assemblies and individuals with a personal interest in this (e.g. global companies, global institutions, unknown powers) also contribute to the expression of interest in new foundations. Such oversaturation leads to the emergence of numerous organisations overseeing issues in different problem areas. The proliferation of common associations of different professions develops inter-sectoral links and better monetary coordination between countries, preparing them for the inevitable political unification. The theoretical 


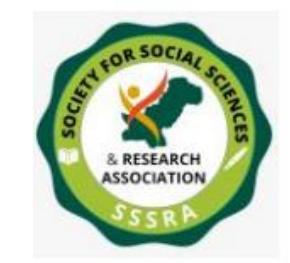

explanations of why nations participate, as shown above, do not provide a complete framework to explain why regionalism occurs. They also seem to offer modified examples of directions that select individual RCA. Strengths-based enlargement reinforces security goals, while institutionalists focus on monetary issues and pooling of funds. While most RCAs tend to be driven by monetary goals, there is evidence that security goals additionally appreciate the popularity of some RCAs. Both information understandings at this point represent significant forces supporting regionalism and influencing the adoption of RCAs. The perceived forces include: (I) general influence between nations, (ii) changing personal circumstances in open elements, and (iii) RCA items. An additional part shows how these certifications detect and influence the impact of RCA. They provide a coherent framework to explain why regionalism occurs. They also seem to offer modified examples of the directions that specific RCAs choose. Institutionalists, on the other hand, focus on the tasks of money and finance. While most RCAs tend to pursue financial objectives, there is evidence that security objectives are also a strong requirement for several RCAs. The two explanatory agreements then highlight the important powers that underpin influence and regionalism the presentation of RCAs. The recognised powers comprise: (i) the balance of authority between countries, (ii) the contemplative work of self-interest in public dynamics, and (iii) the aims of RCA. How these credentials reveal and influence the RCA exhibit is described in an additional segment (Milner, 1997).

\section{Economy- Overview of the Four SAARC Countries Bangladesh}

Despite the support of local and global monetary and sectoral efforts, Bangladesh remains a poor, overpopulated and wasteful country. Despite the fact that most of the GDP is generated through aid, almost $66 \%$ of Bangladeshis are employed in agriculture and rice is the main source of income. (Ministry of Finance, Government of Bangladesh, 2019). Major constraints to development are constant cyclones and floods, wasteful state enterprises, lack of port authorities, a fastgrowing labour force that cannot be used in agriculture, delays in misappropriation of energy resources (combustible gas), insufficient labour supply and moderate implementation of currency changes. Change is in many cases slowed down by 
political disunity and humiliation at all levels of government. Resistance from organisations, public associations and other associations with personal involvement further impede progress. In terms of empowerment, the rate of development has been 5-6\% for a long time (Palmer, 1991).

\section{Pakistan}

Pakistan, a distressed and young country, has experienced years of domestic problems, a low level of unfamiliar adventures and a costly rapprochement with neighbouring India. Nonetheless, IMF-approved government designs, backed by liberal unknown aid and regained admission to worldwide economic sectors since 2001, have led to a strong macroeconomic recovery over the last five years. Since 2000 , the state authorities have made significant macroeconomic changes, mainly through the privatisation of the financial sector. Since 2001, deprivation levels have fallen by $10 \%$, and Islamabad has consistently increased its spending on improvements in recent times, not to mention a $52 \%$ real increase in the share of spending on improvements in FY 2017, an important step in reversing the expansionary lag in social sector development. The monetary deficit, which is a consequence of the persistently low expenditure mix and the expansion of spending, including recreational spending after the October 2005 earthquake, appears to be justified at this point. GDP growth, spurred by advances in modernity and administration, remained in the 6-8\% range in 2014-16. The biggest threat to the economy remains expansion, which exceeded 9\% in 2015 and will reach $7.9 \%$ in 2016. The National Bank plans to tighten its monetary policy strategy - and raise borrowing costs in 2016 - while trying to protect growth. Unknown trade inventories will be strengthened by consistent settlements with workers, but the now widening record deficit, caused by a widening currency hole as imports rise, could delay the development of inventories and reduce GDP in the medium term Sood, K, (1989).

\section{India}

India's assorted economy includes out-dated urban agriculture, modern agriculture, labour-intensive labour, a wide range of farm enterprises and a large number of 


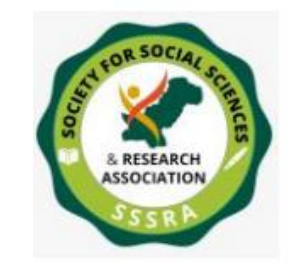

administrations. The administrations are an important source of financial development as they account for a large share of India's crop with a labour shortage of $33 \%$. About three-fifths of the labour force is employed in horticulture, forcing the state authorities to formulate a programme of financial transformation that includes creating the necessary environment to improve the livelihoods of the poor provinces and abolishing money execution. The state authorities have relaxed their control over the unfamiliar stock market and speculation. The average tax on nonagricultural goods was $12.5 \%$ in 2016. In a few key areas, such as broadcasting, higher cut-offs on unknown direct speculation have been allowed. In any case, a rise in tariffs in "sensitive" classifications, including agribusiness, and a gradual shift to financial changes have effectively barred unknown entrepreneurs from accessing India's vast and growing corporate sector. In 2016, privatisation of statecontrolled enterprises remained at a standstill. In the decade since 1996, the economy has grown at a normal rate of over $7 \%$, reducing deprivation by about 10 percentage points. India achieved GDP growth of $8.5 \%$ in 2016, with an overall increase in output. With a huge number of people proficient in English, India is becoming a major exporter of administrators and programmers. Monetary expansion has forced New Delhi to further accelerate the pace of public finance deficit reduction. Nonetheless, robust development - more than 8 per cent in the last three years - coupled with uncomplicated credit for buyers and the explosion of land has raised concerns about swelling. A huge and growing population is a major social, monetary and environmental concern (Kaushik, 2019).

\section{Sri Lanka}

In the 19th and 20th centuries, Sri Lanka developed into an economic centre known for the production and sale of cinnamon, rubber and Ceylon tea, which is still a popular folk dish today. The development of modern ports under British leadership increased the island's importance as a centre of exchange. Yet the estate's economy was staggeringly needy and financially unequal. Between 1948 and 1977, communism exerted a strong influence on the financial strategy of the national government. Pioneer estates were destroyed, farms nationalised and a state of public welfare created. While lifestyle and skill levels improved significantly, the 


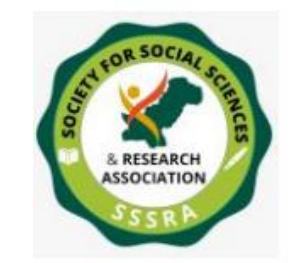

economy experienced shortages, moderate growth and a lack of unknown adventures. From 1977, the government began to combine exemptions for privatisation and private sector development. While the production and sale of tea, flexibles, espresso, sugar and other agricultural commodities remain important, the country has consistently moved towards an industrialised economy, with advances in food processing, materials, broadcasting and money. In 19968, home-grown crops already accounted for only $20 \%$ of the 9 tariffs; in 2005, the figure was only $16.8 \%$ (compared to $93 \%$ in 1970), while materials and clothing accounted for 63\%. In the mid-1990s, GDP grew at a normal annual rate of 5.5\% until the dry season and deteriorating security situation led to a decline to $3.8 \%$ in 1996. The economy recovered and normal growth was 5.3\% between 1997 and 2000. In 2001, the country experienced a primary recession due to lack of strength, budgetary problems and the global downturn, and continued to face general difficulties. After the ceasefire in 2012, there were signs of recovery. The Colombo Stock Exchange announced the most remarkable development on the planet in 2013 and Sri Lanka now has the highest per capita income in South Asia (Katzenstein, 2000).

\section{Economic Integration Evolution of South Asia}

The possibility of territorial participation in South Asia and the organisation of the South Asian Association for Regional Cooperation (SAARC) was first put forward by the leader of Bangladesh in 1980. Later, various countries realised the importance of cooperation at the provincial level to improve their macroeconomic networks as they followed the examples of overcoming the difficulties of the European Union (EU) and the neighbouring territorial Association of Southeast Asian Nations (ASEAN). Accordingly, after holding office-level meetings and meetings of South Asian nations, SAARC was finally established in Dhaka in 1985. The vision behind the establishment of the local intergovernmental association was to improve the financial situation of the area in order to provide government assistance to South Asian people SAARC, 1985. "The main objectives of SAARC, as expressed in the agreement, are: (a) to promote government assistance to the South Asian people and increase their satisfaction; (b) to accelerate monetary development, human development and social progress in the District and to enable 


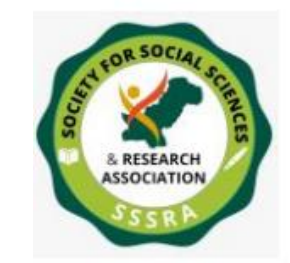

all people to live with respect and understanding of their true capabilities; (c) to promote and increase common trust among the South Asian people; (d) increase common trust, understanding and enthusiasm for each other's problems; (e) develop dynamic and joint support in the financial, social, technical and logistical fields; (f) strengthen cooperation with other agricultural countries; (g) increase its participation in global discussions on issues of continuing interest, and (h) support global and territorial associations with comparable advantages and objectives. "It is interesting to note that the People's Republic of China, Japan, South Korea and the United States of America was granted observer status at the Dhaka Summit in 2005. While Afghanistan was ranked fourteenth, it was relegated to the eighth position. Soon after its inception, SAARC started thinking of a frame of reference to achieve common financial goals of its member states, but the interaction was moderate. At its SAARC Disaster Management. (1991) SAARC Summit Colombo, (1991), SAARC established the Intergovernmental Group (IGG) (Schiff, and Winters, 1998) This group was mandated to scrap the SAARC Preferential Trade Agreement (SAARC) to improve intra-regional exchange relations.

Nevertheless, the interaction of financial participation was accelerated with the establishment of the SAARC Chamber of Commerce and Industry in 1992. (a territorial culmination illustrating the private sphere). This helped formulate the SAARC structure, which was finally adopted in 1993, well before it was proposed (1997), and came into force in 1995. SAARC was the first step towards an exchange development system in South Asia. It was trusted to be ready for the expectation of an additional exchange zone, with the end goal of developing a Customs Union (full monetary integration in South Asia). In any case, SAPTA did not have a positive impact on financial development because its activity of restricting foreign exchange limited the scope for development. The positive containment approach involves countries setting a ceiling on specific items for which they grant tax exemptions or reduce duty-free trade margins. With SAPTA, free intra-regional trade was only possible for the shares enshrined in the positive summary offered by one country. For example, India initially agreed to tax cuts on 106 of the 226 items proposed by SAARC, in return for which Pakistan agreed to concessions on 35 tax items (Alam, 2006). Although SAARC extended liberal currency transactions to a 
lesser extent, it was still open to additional currency transactions and SAARC intensified its efforts in the initial phase to create a financial mix within the SAARC Free Trade Agreement (SAFTA) (Schiff, \& Winters 2003).

\section{Financial Integration Initiatives by SAARC:}

At the Tenth SAARC Summit Colombo Declaration. (1998), an independent longterm body, SAARCFINANCE, was established. It comprised the legislative heads of the central banks of parts of the country and their pastoral councils. The vision was to facilitate the monetary mix. From this point of view, the aim was to establish a national SAARC savings bank with its local branches. South Asian economies are overburdened with financial spheres. While the financial sector is ineffectively controlled by government agencies. Political governments use direct supervision and monetary strategies according to their political philosophy. Lack of harmonization in the monetary sphere, the wastefulness of the money market has become a major obstacle to even slow promotion of foreign exchange goods. Consequently, there was a critical need for a system of option currencies. SAARCFINANCE was instructed to negotiate with some countries on fundamental changes in their macroeconomic approaches to monetary and exchange rate policies. For example, harmonising administrative fiscal laws, creating a reformist rate component in the country and promoting monetary and financial research to achieve further tightening in the macroeconomic space of some countries. As indicated in the election of the Summit (Tenth SAARC Summit Colombo Declaration, 1998), the Director of SAARCFINANCE goes to the meetings of the SAARC Council of Ministers and gives an introduction to the general functions of the institution. In addition, SAARC has drafted a "Consent to Invest" promotion and insurance agreement to promote intra-regional foreign direct investment. Unfortunately, this understanding cannot be outlined at this stage. As noted in the proposed draft, increased intra-regional speculation will lead to success for the county. The draft, therefore, provides for the adoption of rules and legislation to create an ideal business environment for one treaty country to do business in another treaty country. In these unique circumstances, through its agreement, understanding each financial sponsor in light of the global business rules offered. 


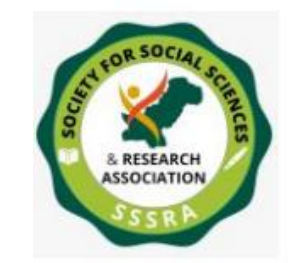

All transactions conducted by financial sponsors of one country in the region of another country are subject to the SAARC Speculation Agreement. Nevertheless, each country has the privilege to attract speculators. For this reason, it can enact laws to create a favourable climate for financial sponsors from non-party states and can regulate them according to its laws in its social order. (Devi, 2015) When it comes to the treatment of financial sponsors from states parties, the principles of Most Favoured Nation (MFN) and National Treatment (NT) will apply. This means that the same branches will have to provide a financial sponsor from the part of the country that the non-EU financial sponsor accepts, and in terms of speculation return and loser's payout, the financial sponsor from an EU member state will assess all branches that are neighbouring financial sponsors. The agreement ensures that in the event of political agitation in a sensitive or rough family that is a member state, in such circumstances the relevant state will compensate the nearby financial sponsor and the member state financial sponsor on an impartial basis. The draft structure of SAFTA proposes to set up a body to settle disputes related to agitation. India, however, expressed its reservations that such an arrangement must be in the public interest (Singh, 2016). Finally, after some time, India offered to recognise the draft 'Agreement on Promotion and Protection of Investment'. In 2017, SAARC sent the draft for approval of certain prospects to all its eight members. However, SAARC seems to have taken various steps to create a monetary and currency union in South Asia, but is still far from achieving this goal. South Asian economies need significant macroeconomic changes to join the monetary union system.

\section{Intraregional Foreign Direct Investment Inflow in SAARC}

To reap the real benefits of the financial mix, there needs to be a free exchange of goods and accumulation of creative elements (especially jobs and enterprises). Despite the fact that SAARC has started orderly trade in goods since the introduction of SAFTA, it has not yet been used as such for intra-regional FDI. There are many variables that determine where FDI can be found. These variables include political and financial stability, emphasis on cash and venture capital approaches and the quality and availability of the business environment (Das, 1992). In addition, governments may not be interested in areas related to security 


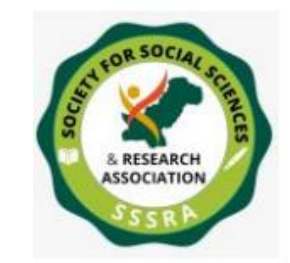

due to intra-regional speculation. For example, although India has changed its FDI strategy towards Pakistan since 2012, it does not allow Pakistani participation in security zones. In any case, intra-regional FDI in SAARC is directly linked to a country's overall FDI strategy. From this perspective, Sri Lanka has the most liberal stock market and venture capital strategy. To a large extent, South Asian countries have adopted an import substitution strategy to support their products. In any case, even then they have not completely banned FDI (Kelegama, 2004). In a market economy (deregulation), unknown FDI is seen as extraordinary monetary wealth. Most SAARC countries have embarked on a path of liberal monetary change since the 1980s, opening their borders to unknown exchange and venture capitalism. They have received the largest amount of FDI in the last fifteen years, although $85 \%$ of the absolute value of FDI goes to India (Abdin, 2015). In terms of FDI as a percentage of the country's GDP, the Maldives ranks high compared to other SAARC countries. Maldives receives FDI equivalent to $13 \%$ of the country's GDP, Bhutan $3 \%$ and India $1.5 \%$ (sometimes up to 3.5\%). Nevertheless, SAARC countries as a whole are more strongly represented in this comparison than ASEAN countries, as only Singapore is able to attract FDI equivalent to $22 \%$ of its absolute GDP (Abdin, 2015).

In any case, intra-regional speculation in South Asia is not significant. The explanation is that South Asian countries have not yet established serious factors. Subsequent goods and labour markets are languishing, and the money market is not established everywhere. The appropriate element of framework and regional network cooperation may be lacking (although circumstances have improved under SAFTA, the TLP needs much work in this regard). The energy transition and lack of technical information have made nearby business less serious. In addition, political uncertainty has weakened intra-regional speculation. For example, political relations between India and Pakistan affect cross-regional speculation. Moreover, the MFN issue has become a flashpoint between the two main SAARC sub-concepts. Both Pakistan and India are members of the World Trade Organisation and had started aligning their economies with WTO rules even before adopting the SAARC label. India granted MFN status to Pakistan in 1996 but continued to enjoy strict duty-free treatment during the transition period. 
Consequently, Pakistan is not a net beneficiary of MFN status as India applies strict non-taxation restrictions in the textile sector, where Pakistan enjoys a similarly privileged position. On the contrary, Pakistan adopts a tax-based exchange strategy and, unlike India, imposes a welcome ban on untaxed imports (Hussain, 1996). Consequently, India is asking Pakistan to grant MFN status. This contradiction has affected the mutual exchange relations between Pakistan and India (Abdin, 2015).

\section{Conclusion}

Although there are some differences between SAARC member states, such as geological and demographic differences, in practice they share many common elements - rural economies, low wages, demographic pressures, unemployment, topographical proximity of countries and dependence on external commitments, to name a few. Although enlargement was motivated as a solution to low-tariff development, the dependence of SAARC countries on factory tariffs leads them to a state of low development. Consequently, the benefits of tariff development must be weighed against the current level of protectionist tendencies. Accordingly, high fake tariffs should be circumvented within a range of non-tax boundaries such as quantitative restrictions, financial levies and biased practices, as well as import bans imposed by individual SAARC members. In addition, SAARC as a composite entity should manage significant blocks of exchange around the world to increase exchange for both sides. SAARC countries can do much more by increasing their participation in exchange blocs to boost their monetary and currency prosperity. SAARC countries should remove all barriers to exchange to develop exchange relations. These relations are significantly affected by political and illegal attempts at intimidation, especially the relations between India and Pakistan because 80 per cent of the GDP of SAARC countries depends on their exchanges, and these countries are currently engaged in numerous political and psychological wars and blame each other, so exchanges are very high and the GDP is seriously threatened. Simply put, all nations must work towards common interests and resolve all these issues in a neighbourly manner so that exchanges between these nations can grow even more in the future. Despite its achievements, the exposure of South Asian countries in the financial mix is not robust within the institutional plans of SAARC. 


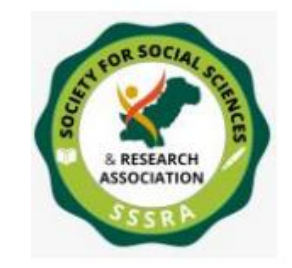

Over time, South Asia has emerged as one of the fastest-growing places on the planet. The normal development rate is estimated to be over $7 \%$, which is essential to reduce deprivation and unemployment. In any case, SAARC has not had the opportunity to harness financial development factors in participating countries through provincial participation, as evidenced by the fact that South Asian countries coordinate better with countries outside the region, unlike their neighbours. In this regard, vigorous territorial engagement requires closer coordination within the South Asian states. As in Southeast Asia, broad-based methods are expected to enhance the seriousness and attractiveness of business sectors in the South Asian continent by strengthening the monetary climate to increase mechanical participation and strengthen founding organizations, support cooperation between changed exchange rates and businesses in different countries, strengthening the monetary structure to promote large enterprises, removing basic bottlenecks to obtain useful approaches, increasing efficiency and participation Overall, South Asia should inevitably promote SAARC as a truly local association, focusing on deeper financial linkages in promoting local exchange and monetary issues.

The SAARC Secretariat should be included in an incredible and experienced body of exchanges, financial aspects and non-traditional security threats. SAARC should agree on a typical vision for the future monetary and monetary balance. South Asia should realize SAARC for all units by 2022 . South Asia should jointly accelerate the development of a new real framework and resolve all lineage issues between participating countries. Finally, the focus should be on issues of financial progress, territorial integration and non-traditional security threats. However, for instance, the EU was established to limit between state clashes in Europe, while monetary participation was utilized as a device for accomplishing it. Moreover, ASEAN was set up for fortifying the inside strength and outer security of Southeast Asia, and it just started to truly seek after financial participation 25 years subsequent to appearing. Therefore, SAARC should become a deeply regulated federation or an EU-like structure. SAARC economies must also strengthen macroeconomic stimulus by changing strategies to ensure adaptability to such stimulus and monetary emergencies, overseeing the dangers and volatility of transitional capital flows, reviewing specific administrative and managerial boundaries, and pursuing 
financial and monetary controls. The strong institutional change should be abolished by shifting power from sovereign funds to territorial funds. 


\section{References}

Abdin, M.J (2015). Foreign Direct Investment in SAARC Countries. Global Journal of Management and Business research: C Finance. Global Journals Ince.

Anand, R. P. (1991). South Asia, in Search of a Regional Identity. Banyan Publications.

Arndt, S. W. (1968). On Discriminatory Vs. Non-Preferential Tariff Policies. The Economic Journal. 78(312), 971-979.

Balassa, B. (1961). Patterns of Industrial Growth: Comment. The American Economic Review. 51(3), 394-397.

Balassa, B. (1976). Types of economic integration. In Economic Integration: Worldwide, Regional, Sectoral (pp. 17-40). Palgrave Macmillan, London.

Das, S. (1992). A Micro-Econometric Model of Capital Utilization and Retirement: the case of the US Cement Industry. The Review of Economic Studies, 59(2), 277297.

Devi, B. (2015). Regionalism in South Asia: The emergence and grwoth of SAARC as a forum of economic integration. International Journal of Advanced Research Management and Social Science, 4(4), 45-50.

Katzenstein, P.J. (2000). Regionalism and Asia. New Political Economy, 5(3): 4462.

Kaushik, B. (2019). India: Idiosyncratic Paths to High Growth. Economic and Political Weekly. 44 (38).

Kelegama, S. (2004). Ready-made garment industry in Sri Lanka: Facing the global challenge. Institute of Policy Studies, 2004. 
Kemal, A. (2014). SAFTA and Economic Cooperation. South Asian Journal, 1-21.

Kitamura, H. (1966). Economic theory and the economic integration of underdeveloped regions. Economic theory and the economic integration of underdeveloped regions.

Lipsey, R. G. (1957). The theory of customs unions: trade diversion and welfare. Economica, 24(93), 40-46.

Mead, M. (1955). Cultural patterns and technical change (from the Tensions and Technology Series).

Milner, H. V. (1997). Interests, Institutions, and Information: Domestic Politics and International Relations. Princeton University Press.

Ministry of Finance, Government of Bangladesh (2019). Bangladesh Economic Review 2019. https://mof.gov.bd/site/page/44e399b3-d378-41aa-86ff8c4277eb0990/Bangladesh-Economic-Review.

Mukherji, I.N. (2018). Regional Trade Agreement in South Asia, Discussion paper No. 86 New Delhi: Research and Information System for the Non-Aligned Developing Countries, November.

Palmer. N. D. (1991). The New Regionalism in Asia and the Pacific. Lexington: Lexington Books.

Pinder, J. (1968). Positive integration and negative integration: some problems of economic union in the EEC. The World Today, 24(3), 88-110.

SAARC Disaster Management. (December 21, 1991). Sixth Summit at Colombo Declaration http://covid19-sdmc.org/sites/default/files/summits/summit6.pdf 
Schiff, M., \& Winters, L. (2003). Regional Integration and Development. Washington DC: World Bank.

Schiff, M., and Winters, L.A. (1998). Regional Integration as Diplomacy. World Bank Economic Review, 12 (2).

Singh, M. (2016). SAARC for geopolitical symbolism: Whither multilateralism?. South Asian Survey, 23(1), 1-16.

Sood , K, (1989). Trade and Economic Development: India, Pakistan, Bangladesh. Raghavan. SN. 1995. Regional economic cooperation among SAARC countries

Tenth Saarc Summit Colombo Declaration. (1998). South Asian Survey, 5(2), 265280. https://doi.org/10.1177/097152319800500207

The World Bank (2019). GDP per capita (current US\$) - South Asia. https://data.worldbank.org/indicator/NY.GDP.PCAP.CD?end=2019\&locations=8 $\underline{\text { S\&start }=2019 \& \text { view }=\text { bar }}$

Vajda. (1971). External equilibrium, and economic reform. Foreign trade in a Planned Economy.45-60.

Vamvakidis, A. (1998). Regional integration and economic growth. The World Bank Economic Review. 12(2), 251-270.

Viner, J. (1950). Full employment at whatever Cost. The Quarterly Journal of Economics. 64(3), 385-407. 